DOI: 10.20472/TEC.2019.008.018

ELSA MENTZ

Self-Directed Learning, North-West University, South Africa

JOSEF DE BEER

Self-Directed Learning, North-West University, South Africa

\title{
THE AFFORDANCES OF CHANGE LABORATORIES FOR IMPROVED SUSTAINABILITY AND IMPACT OF IN-SERVICE TEACHER PROFESSIONAL DEVELOPMENT PROGRAMMES
}

\begin{abstract}
:
The leitmotif underpinning this paper is the affordances of third-generation and nascent fourth-generation Cultural-Historical Activity Theory (CHAT) as a research lens, when analyzing complex systems such as teacher professional development. The context is a design-based research study on short learning programmes (SLP's) for science teachers. The SLP's focus on teacher professional development to contextualize science curriculum themes through the infusion of indigenous knowledge. In the SLP's inquiry learning, cooperative learning and self-directed learning are emphasized. The data showed that, although the teachers benefited from the SLP's, and were both more capable and enthusiastic to engage in transformed teaching practices after the intervention, transfer of the newly acquired knowledge and skills to the classroom did not take place in many cases. This lead to the formulation of the research question underpinning this paper: how can the impact and sustainability of well-designed SLP's be ensured? Third-generation CHAT provided insights into the tensions that negatively impacted on the realization of the activity system's 'object'. The 'contradiction of control'- a phrase referring to the fact that different stakeholders had different views and impact on the object- prompted the authors to start planning the implementation of Change Laboratories, and the utilization of fourth-generation Cultural-Historical Activity Theory. For example, many teachers indicated that the expectations of principals and parents that they should 'teach to the test' incited them to fall back on transmission-mode approaches, at the expense of the more learner-centered approaches that they were introduced to during the SLP's. Change Laboratories provide a space where all stakeholders engage in expansive learning, and attempt to come to a shared understanding of the object. By shifting the gaze to fourth generation CHAT, where all stakeholders are seen as different activity systems, researchers might gain insight in how tensions that corrode the realization of the object could be reduced. The paper concludes by providing a number of design principles for such Change Laboratories, such as that the elements of cooperative learning should be guiding the discourse.
\end{abstract}

\section{Keywords:}

Cultural-Historical Activity Theory, teacher professional development, indigenous knowledge, self-directed learning, expansive learning, social interdependence theory, cooperative learning, Change Laboratories

JEL Classification: 123, 121, 129 


\section{Background and problem statement}

South African education has been in a flux of change since the dawn of its democracy in 1994. Unfortunately, it is a case of 'the more we change, the more we stay the same'. Despite a progressive national school curriculum, which advocates for a focus on 21 st century skills, most South African school classrooms are still characterized by transmission-mode teaching and learning practices. Research (e.g. that by Ramnarain and Schuster, 2014) have shown that many South African teachers hold the belief that direct instruction (e.g. 'lecturing') is the best way to prepare learners for summative assessment opportunities. This generic problem is true of all subjects, also the natural sciences.

South African learners perform poorly in international benchmark tests such as the Trends in Mathematics and Science Study (TIMSS). The literature provides many reasons for this unfortunately state of affairs, for example, a lack of resources (De Beer \& Ramnarain 2012), but most research points to the fact that the most important factor in ensuring high-quality education, is the quality of the teacher. Research by Bernstein (2011) and the McKinsey study (2007) (Barber \& Mourshed, 2007) make it clear that an education system can only be as good as the quality of its teachers. For this reason, both pre-service and in-service teacher education is an issue of great concern. Various approaches to professional development have been implemented in South Africa the past three decades, such as teacher professional groups ("clusters"), where teachers, within small communities of practice, support each other in professional development activities (Pretorius, 2015). The problem with these professional development groups, were that it mostly became a moderation session for learners' portfolios (focus on assessment), and did not support teachers in their professional development needs. Furthermore, there were initiatives such as the Dinaledi School project and the LEAP (Leadership, Effectiveness, Accountability and Professionalism) school enterprise, which also had limited success in terms of teacher professional development (Pretorius, 2015). One of the ways in which teacher professional development can be supported, is through short learning programs (SLP's). However, SLP's are also criticized. The CDE report (2011) makes it clear that the once-off, piecemeal approaches to professional development (e.g. workshops) are not effective, and that teacher professional development is best supported within supporting communities of practice.

Mindful of this context, we developed a short learning program (SLP) for natural sciences teachers, that would support them in their professional development, even after the formal short learning program. The focus of the SLP is on supporting teachers in the epistemological border-crossing between science and indigenous knowledge, in an attempt to better contextualize the curriculum for a diversity of South African learners. This should further be seen against the background of the "decolonization of the curriculum" debate that became prominent in South Africa since 
2015. We are of the opinion that one way of "decolonizing" the curriculum, is through the infusion of indigenous knowledge in the school curriculum. We wanted to adopt an approach where we explore the shared tenets of science and indigenous knowledge, e.g. both have an empirical, tentative and inferential nature (Cronje, De Beer and Ankiewicz, 2015). Teachers engaged in learner-centered activities, and we especially emphasized problem-based and cooperative learning activities in the SLP. A further trademark of the SLP's was that it was underpinned by a research agenda within the context of self-directed learning. (Teachers were required to identify professional learning goals for themselves, and to implement strategies, and to monitor, their own learning) (cf. Knowles, 1975).

After each intervention (SLP), data was collected through questionnaires, personal interviews with the teachers, portfolios and classroom observations. Teachers needed to submit portfolios six weeks after the SLP, and classroom observations (making use of the Reformed Teaching Observation Protocol) (Sawada, Piburn \& Judson, 2002) were done to obtain information about the sustainability of the SLP's. Our findings, which are reported in other publications (De Beer \& Mentz, 2016, Mentz \& De Beer, 2017; Mentz \& de Beer, 2019) provide sufficient evidence that the SLP's were successful in providing teachers with more nuanced understandings of indigenous knowledge, problem-based learning, cooperative learning and self-directed learning. However, the data also clearly highlighted the fact that transfer of this knowledge and skills did not always take place in the classroom. Although affective outcomes were definitely achieved during the SLP, in so far that the teachers enjoyed the indigenous knowledge, problem-based and cooperative learning activities, and appreciated its value, teachers indicated that there are tensions (external pressures) that prevented its implementation in their classrooms. Such tensions were, amongst others, the time schedule that accompany the curriculum (the so-called 'pace setter'), and expectations by principals and parents who often favor direct instruction (e.g. lecturing) over inquiry learning approaches.

This conundrum has led to the following research question: How can the impact and sustainability of well-designed SLP's be ensured?

To answer the research question we are going to elaborate on CHAT as a lens for our research within a social constructivist paradigm. Theories underpinning social interaction for learning will be discussed thereafter. Change Laboratories as boundary crossing learning spaces and expansive learning as part of the solution to ensure the sustainability of SLP's will then be elaborated on. We end with certain design principles for Change Laboratories.

\section{CHAT as a lens for educational research}

Cultural-Historical Activity theory rhizomically arose from Vygotsky's Social Constructivist ideas in the early 1920's. Early researchers such as Leont'ev (1978) 
and Luria (1976) further built on Vygotsky's central premise of learning mediation. Vygotsky (1978) was of the opinion that the learner (subject) acted upon certain mediating objects in their environment such as tools, signs and instruments. The subject within the CHAT framework is the person involved in the activity, using mediating artifacts to change the object, which provides specific direction and motivates the activity (Igira \& Gregory, 2009). This idea of mediation was the basis of first generation CHAT. According to Engeström (2001) a weakness of first generation CHAT is the restrictive focus on the individual as unit of analysis, ignoring collective activities that characterizes most learning environments.

Engeström (1987) is given credit for the development of second generation CHAT (Nussbaumer, 2011), drawing on the work of Vygotsky (1978) and Leont'ev (1978) (Igira \& Gregory, 2009). Second generation CHAT emphasizes the individual learning in interrelationship with the broader community. Engeström (1987) developed the concept of an activity system to understand the sociocultural context in which people are embedded and with which they interact (Igira \& Gregory, 2009). In an activity system the subject of the activity is motivated by a specific purpose (object), and is influenced by rules, tools, the community and the division of labour in order to achieve the outcome. People continually create new objects and change existing objects through their activities (Engeström, 2008).

Cole (1988) critized second generation CHAT for its insensitivity towards cultural diversity and in collaboration with Engeström (2001) they paved the way for third generation CHAT in which "networks of interactive systems [to] deal with tensions and contradictions that encourage collective learning through change" (Nussbaumer, 2011: 39). The unit of analysis in $3^{\text {rd }}$ generation CHAT, consists of at least two interacting activity systems to be able to understand "dialogue, multiple perspectives, and networks of interacting activity systems" (Engeström, 2001). In previously published work (De Beer \& Mentz, 2016, Mentz \& De Beer, 2017; Mentz \& De Beer, 2019) we provided context of such juxtaposed activity systems (e.g. the short learning program, and transfer in the classroom afterwards). Multiple interconnected activity systems with shared objects are the unit of analysis (Engström, 2008). Such networks of interactive activity systems allow for boundary-crossing between them (Igira \&Gregory, 2009). Some of these objects may be contested or generate controversy (runaway objects) (Engeström, 2008) but they might also open up new innovative possibilities. Sometimes the boundaries of runaway objects are vague, but still, there needs to be interaction among participants when acting on the object (Engeström, 2008:3). Veresov (2010) stresses the importance of interaction as a main concept of CHAT.

The elements of the activity system are in interaction with each other while tensions and contradictions between them result in transformative change in the activity system, which might even lead to reformulation of the object (Igra \& Gregory, 2009). External influences "change some elements of activities, causing imbalances between 
them". (Kuuti, 1996:34) According to Engeström (2001:137) contradictions, as "historically accumulating structural tensions within and between activity systems play a central role as sources of change" as it may cause conflicts but also might result in innovative ways to change the activity. Kuuti (1996:34) agrees and sees such contradictions (eg. "problems, ruptures, breakdowns and clashes") as sources of development. People constantly create new objects through their activities of which some could be contested and cause controversy, and other can be powerful and developmental of nature (Engeström 2008).

Engeström (2001) identifies five principles of activity theory:

i) The unit of analysis is always an activity system that is directed towards a specific object. The latter is achieved through artifact mediated tools and should always be seen in its connection to other activity systems. (In our case, the 'object' is professional development of teachers to infuse indigenous knowledge effectively in the classroom with the help of teaching strategies which foster self-directed learning);

ii) Activity systems embodies various perspectives, customs and interests. The multi-voicedness of activity systems could lead to innovation, but could be seen as a source for conflict;

iii) Activity systems develop in a historical context over time;

iv) In an activity system contradictions play a central role as catalysts of change and development;

v) Activity systems has the potential of expansive transformations.

Based on CHAT-methodology, Igira and Gregory (2009) stated that developmental work research focuses on the study of change and development to understand processes of change in work practices. According to Gretschel, Ramugondo and Galvaan (2015) CHAT can be used to study the activities of people (as the subjects) within an activity system as it enables the researcher to view and analyse the complex activity within its cultural, historical and economical dimensions, while also being able to study the different components of the activity system separately. CHAT can thus provide an excellent lens to study complex systems at a certain stage or over a given time span as is the case with teacher professional development through SLP' as discussed above. 


\section{Cultural-Historical Activity Theory as a lens in our specific design-based research}

We have utilized the third generation CHAT in our design based research as a lens to analyse our data. The affordances of CHAT to our research has been published elsewhere, (De Beer \& Mentz, 2016, Mentz \& De Beer, 2017; Mentz \& de Beer, 2019), but in the context of this paper we would like to briefly flag the utility value of CHAT. If one considers the SLP as an activity system, the object should be seen as the professional development of the Science Teacher. This is a nuanced object that centralizes the role of self-directed learning in developing skills to contextualize Science Education, using cooperative and inquiry learning approaches. CHAT provides a useful heuristic to develop an understanding of how the tools (e.g. pedagogies or learning resources), rules (e.g. curriculum requirements, pace setters, tenets of science, elements of cooperative learning), the community (e.g. parents, principals, learners), and the division of labor (e.g. the different roles played by the actors) influence the envisaged object. CHAT as a barometer of tensions indicate how the different nodes in the activity system could erode the envisaged object. The tensions could develop from any of the nodes, and often lead to what McNeil (2013) calls the contradiction of control. Our research, for instance, have shown that, due to pressure from principles and parents, and the department of education's pace setters, the teachers often fall back on familiar tools such as the lecture method (despite their buy in on active learning strategies during the SLP) after the SLP in their classrooms. Engeström (1978) states that in $3^{\text {rd }}$ generation CHAT, at least two interdependent activity system should be the minimum unit of analysis. In our research we have often juxtaposed the SLP as an activity system, with that of the post SLP classroom.

Whereas most teachers bought into the object of active learner centered teaching and learning during the SLP, this object was compromised in many of the classrooms after the SLP.

\section{Warford's 'zone of proximal development' (ZPTD) within the social constructivist theory}

One of the key theories underpinning this research (as well as CHAT) is social constructivism (Vygotsky, 1978). Although Vygotsky published his research in the 1920 's, his work only became popular in the western world in the 1970's, forty years after his untimely death. Kozulin (2004) ascribes this to the fact that Vygotsky's emphasis of the sociocultural dimensions of learning did not resonate much with scholars who mainly worked in those times within two paradigms: "traditionalists" and behaviorists on the one hand, which emphasized transmission-mode teaching and learning, and "progressivists" who promoted discovery learning on the other hand. These paradigms saw learners, in Kozulin (2004:3) parlance, as "individuals processing natural functions of perception, memory, and problem solving that should be used for the transmission of learning". The role of social learning and the environment received little attention. Veresov (2010) poses that human mind 
development is a cultural-social process. According to Vygotsky, learning takes place on two planes: first on a social level, where meaning is collectively constructed, and then on a personal plane, where this knowledge is internalized:

'Any function in the child's cultural development appears twice, or on two planes. First it appears on the social plane, and then on the psychological plane. First it appears between people as an interpsychological category, and then within the child as an intrapsychological category. This is equally true with regard to voluntary attention, logical memory, the formation of concepts, and the development of volition... It goes without saying that internalization transforms the process itself and changes its structure and functions. Social relations or relations among people genetically underlie all higher functions and their relationships'. (Vygotsky, 1981:163).

Within the zone of proximal development (Vygotsky, 1978), the learner is scaffolded in his/her learning through tool mediation and more knowledgeable others. An aspect that is often forgotten in such discourse, is Vygotsky's emphasis of the role of cognitive disequilibrium in the learning process. Learning, according to Vygotsky, "involves periods of relative stability interspersed with 'crises'- the periods of dramatical change that lead to the emergence of the new quasi-stable structures" (Kozulin, 2002:9). To this effect, Veresov 2010:88) speaks of "dramatical collisions", and he concludes that "such emotionally experienced collisions can bring radical changes to the individual's mind, and therefore can be an act of development of mental functions". For Veresov (2010:88), the "internal drama" accompanying cognitive dissonance is an essential element in conceptual change.

Scaffolding learning across this zone of proximal development, from the actual development to potential development, is influenced by a myriad of factors, and this is why Cultural-Historical Activity Theory, which is embedded within social constructivism, is a powerful lens when researching learning. Both the short learning programs discussed earlier on in the paper, and the Change Laboratories which are mentioned later, are built on Warford's (2011) take on Vygotsky's ZPD. Warford (2011) coined a mutation on the classic construct of the 'zone of proximal development' (ZPD) of Vygotsky, and speaks of the 'zone of proximal teacher development' (ZPTD) of teachers. Warford proposes four stages in scaffolding (teachers') learning across this zone of proximal teacher development (Warford, $2011: 255)$. Stage 1 expects learners (teachers, in our case) to reflect on their prior experiences and assumptions. During stage 2, which Warford calls the 'expert-other stage', the learners is confronted with alternative viewpoints. Meaning is socially constructed, and is best facilitated, in our view, through cooperative learning. Stage 3 entails internalization, and this requires individuals to rethink their own viewpoints, and adapt their schemata (Piaget, 1970). In the context of this SLP, accommodation of new constructs is often needed within existing schemata. Piaget (1970:708) describes such accommodation as 'necessary to permit structural change, the transformation of 
structures as a function of the new elements encountered'. For example, teachers have to accommodate their new insights into the tenets of indigenous knowledge, the new insights about self-directed learning and strategies to enhance it, within their prior views (schemata) on the nature of science. The fourth stage, the recursion or deautomatization phase, is the 'theory to practice' stage, where the learning is applied in practice. Later on, we will show how the ZPD will also apply to the Change Laboratories.

\section{Theories underpinning social interaction for learning}

Another theory underpinning this research is that of social interdependence. Social interdependence theory is of significance in terms of both the SLP's, as well as the intended Change Laboratories. Deutsch (1949) builds on the theories of Koffka (1935) and Lewin (1935) and introduced the Social Interdependence Theory. This is one of the theories from which Johnson and Johnson derived cooperative learning (Johnson, Johnson \& Smith, 1998). Koffka identifies an interdependence among group members functioning as a "dynamic whole" and Lewin stated that "the interdependence among members created by common goals is the essence of a group", where changes in the state of one member influences the state of another member (Johnson \& Johnson, 2018: 4). It focusses on group interaction which is related to a common goal. The interdependence of the group determines the group cooperation. "Different types of social interdependence lead to different types of social interaction" (Roseth, Lee, Saltarelli, 2019: 150). Positive interdependence creates a "sink or swim" effect where the members of the group aim to promote everyone's success in order to promote their own success (Johnson, Johnson \& Stanne, 1989). "Positive interdependence results in promotive interaction (i.e. individuals encouraging and facilitating each other's efforts to complete tasks in order to reach the group's goals)" (Johnson \& Johnson, 2009:366). Negative interdependence on the other hand, occurs when "the actions of the individual obstruct the achievement of each other's goals" (Johnson \& Johnson, 2009:366). In the case of cooperation, the social interdependence is high and positive (Deutsch, 1949). Positive social interdependence groups are in a trustful relationship and committed to achieve their mutual goal, which resulted in positive affective attitudes to enhance group productivity and motivation (Teng \& Luo, 2015, Bartel \& Saavedra, 2000; Chen et al, 2013). Achievement within such a group improves because group members try to promote each other's success through their interaction (Cockerill, Craig \& Thurston, 2018). Deutsch (1994:200) argues that "cooperation induces and is induced by a perceived similarity in beliefs and attitudes, a readiness to be helpful, openness in communication, trusting and friendly attitudes, sensitivity to common interests and de-emphasis of opposed interests, and orientation toward enhancing mutual power rather than power differences." Onwuegbusie, Collins and Jiao (2009) posit that within the Social Interdependence Theory, positive interdependence among the goals of the group members enhances the cooperation. 
Other theories also acknowledged in cooperative learning research is cognitive theories, behavioral theories (Johnson, Johnson \& Smith 1998) and the StructureProcess-Outcome Theory (Johnson \& Johnson, 2018). Within the cognitive theory, scholars like Piaget and Vygotsky believe that learners must socially engage in some form of cognitive restructuring of new knowledge in order to learn (Slavin et.al., 2003). Johnson and Johnson (2018:10) stated that "it is the cooperative structure that promotes students to engage cognitively and emotionally with other students" [and in doing so], "construct, discover and transform their own knowledge".

Within the behavioral theory, motivation is the most important aspect driving the cooperative learning process (Slavin et.al. 2003). Schein (1996) is of the opinion that working in groups create motivation for learning and change.

The Structure-Process-Outcome Theory states that the way in which a group is structured will determine individual engagement and involvement in the achievement of the goal. The outcome will be influenced by the interaction between members of the group and the structuring of the learning goals will determine this interaction (Johnson \& Johnson, 2018). This theory confirms the notion that unstructured collaboration will not necessarily result in positive interdependence or promotive interaction among group members and might not result in individual learning for each member of the group. It is because of the structure of cooperative learning that students "engage cognitively and emotionally" with others to construct and transform their own learning (Johnson \& Johnson, 2018: 10).

When looking at all the theories underlying social interaction in learning, Slavin et al., (2003) is of the opinion that when looking at the larger picture, similar work has been done from different perspectives. All these perspectives can in our view be used to strengthen a good cooperative learning environment as we need to set up for the Change Laboratories.

\section{Change laboratories as boundary crossing learning spaces}

Educational transformation is often dealt with in a top down approach which does not necessarily ensure buy-in from all stakeholders. We often forget the wisdom of Bronfenbrenner (1977:528) who concluded that "research on the ecology of human development should include experiments involving the innovative restructuring of prevailing ecological systems in ways that depart from existing institutional ideologies and structures by redefining goals, roles and activities and providing interconnections between systems previously isolated from each other". Bronfenbrenner emphasized that transformation cannot be controlled but should be influenced and shaped.

Schein (1996:60) believes that "all forms of learning and change start with some form of dissatisfaction or frustration generated by data that disconfirm our expectations or hope". He uses two terms, 'learning anxiety' and 'survival anxiety' when dealing with 
change. "Learning anxiety is the fundamental restraining force which can go up in direct proportion to the amount of disconfirmation, leading to the maintenance of the equilibrium by defensive avoidance of the disconfirming information" (Schein, 1996:60). Survival anxiety is a feeling of guilt when accepting the disconfirming information as important or useful. He argues that only within a psychological safe environment, the disconfirming information will not be resented. In his view "the key to effective change management, then becomes the ability to balance the amount of threat produced by disconfirming data with enough psychological safety to allow the change target to accept the information, feel the survival anxiety, and become motivated to change" (Schein, 1996: 61).

Learning in groups can, according to Schein, (1996:61) reduce learning anxiety and create real motivation for learning and change. Educational transformation can thus best be achieved in collaboration with others. Schön (1987) is in agreement with Schein, and states that a "low-risk setting for novice learning" should be created. Thus the Change Laboratory should be accompanied by 'rules' that will ensure a safe space characterized by cooperative learning.

Engeström, (2011) explains a situation where complex problems involving different stakeholders need to be solved and use the word 'Change Laboratories' as an intervention toolkit in this regard. He describes a Change Laboratory (also sometimes referred to as a Border-Crossing Laboratory) (Engeström, 2001) as "a microcosm in which potential new ways of working can be experienced and experimented with" (Engeström 2011: 612). Typically, researchers would engage in Change Laboratories when major transformation is needed in an activity system (Engeström, Rantavuori \& Kerosuo, 2013). Igira and Gregory (2009:444) explain the purpose of the Change Laboratory as "to help a work team or members of an organization to encounter the problems they face in the work practices and systematically analyze the systemic courses of the problem and design and implement a new form (a new model) for the activity to overcome the route course of daily problems". The Change Laboratory can thus be seen as a place where cooperation between the researchers and local practitioners can take place (Igira \& Gregory, 2009). It consists of five to ten sessions with all stakeholders and researchers where problems in the workplace can be identified to stimulate involvement. Thereafter, conceptual tools are used to facilitate the analysis of the problems and provide solutions. The implementation of solutions will be the next stage in the Change Laboratory. The videotaped laboratory sessions can be used for reflection in following sessions (Engeström, 2011).

When planning a Change Laboratory, the interventionists have to ensure representation by all stakeholders involved. An aim of a change laboratory should be to build cooperative transformative agency and motivation within successive cycles of critical engagement with the problems encountered. In this process participant critically engage with the tensions and contradictions within the activity (Englund \& Price 2018). 
Expansive learning is at the heart of a Change Laboratory. Expansive learning is concerned with the learning of new forms of activity, as they are created. It is furthermore concerned with collective transformation, rather than individual learning (Engeström, 2001).

\section{At the crossroads for teacher professional development: Applying the theory of expansive learning for sustainability, with Change Laboratories}

Based on the tensions alluded to earlier on, we will now enter a new phase in the project, and engage in Change Laboratories. Furthermore, we will be moving towards fourth-generation CHAT in analyzing the "runaway object". Before the Change Laboratory, interviews will be conducted with stakeholders of the different activity systems, namely representatives of the Department of Education, School Governing Bodies and principals, teacher unions, parents, the larger community, teacher education institutions (higher education institutions), and teachers themselves. This will assist the researchers to paint nuanced pictures of the different activity systems, and how each of the activity systems view the "runaway object". (Refer to Figure 1 for a representation of fourth-generation CHAT). Short video-snippets will be made during the abovementioned interviews, and this will be shown during the Change Laboratory to provide context on the views hold by the different stakeholders (activity systems). Engeström (1996) speaks of the "mirror", where videos, problematic cases, statistics and research data, etc. are used for the "analysis of ruptures in the coordination and collaboration between actors" (Virkkunen \& Newnham, 2013). For instance, representatives from Higher Education Institutions might voice their concern about the "wash-out effect" (Zeichner \& Tabachnick, 1981) that often follows teacher professional development interventions, and how we could see more transfer of newly acquired knowledge and skills in the classroom. Teachers might respond by sharing their experiences of having to comply with the "pace setters" (work schedule) provided by the Department, and how this might prevent them from engaging in more inquiry learning approaches. Officials of the Department of Education could react by giving context on why the "pace setters" were implemented. A concerned parent might voice her trepidations that her child is not adequately prepared for summative assessment opportunities. Community members again, might express concern that children are not adequately prepared for a complex $21^{\text {st }}$ Century, which requires skills that are not necessarily addressed through transmission-mode teaching and learning. This creates a learning space where elements such as "struggle"; "resistance" and "subversion" are core ingredients (Engeström, 2011), yet it happens in a safe laboratory space, based on cooperative learning elements. The intention is that stakeholders would come to an agreement on a new, shared object, in order to overcome some of the tensions highlighted by third-generation CHAT. This would take place through expansive learning.

We will be following the phases of the Change Laboratory Process, as explained by Engeström (1996:11), and adapted by Virkkunen and Newnham (2013:17): 
(i) Charting the situation (identifying the overarching problem, getting buy-in on the need for change from all stakeholders)

(ii) Analysing the situation (what are the quandaries and contradictions?)

(iii) Creating a new model (where do we want to be 5 years from now?)

(iv) Concretizing and testing the new model (What changes do we want to implement?)

(v) Implementing the new model (putting the new model into practice)

(vi) Spreading and consolidating (codifying the new practices)

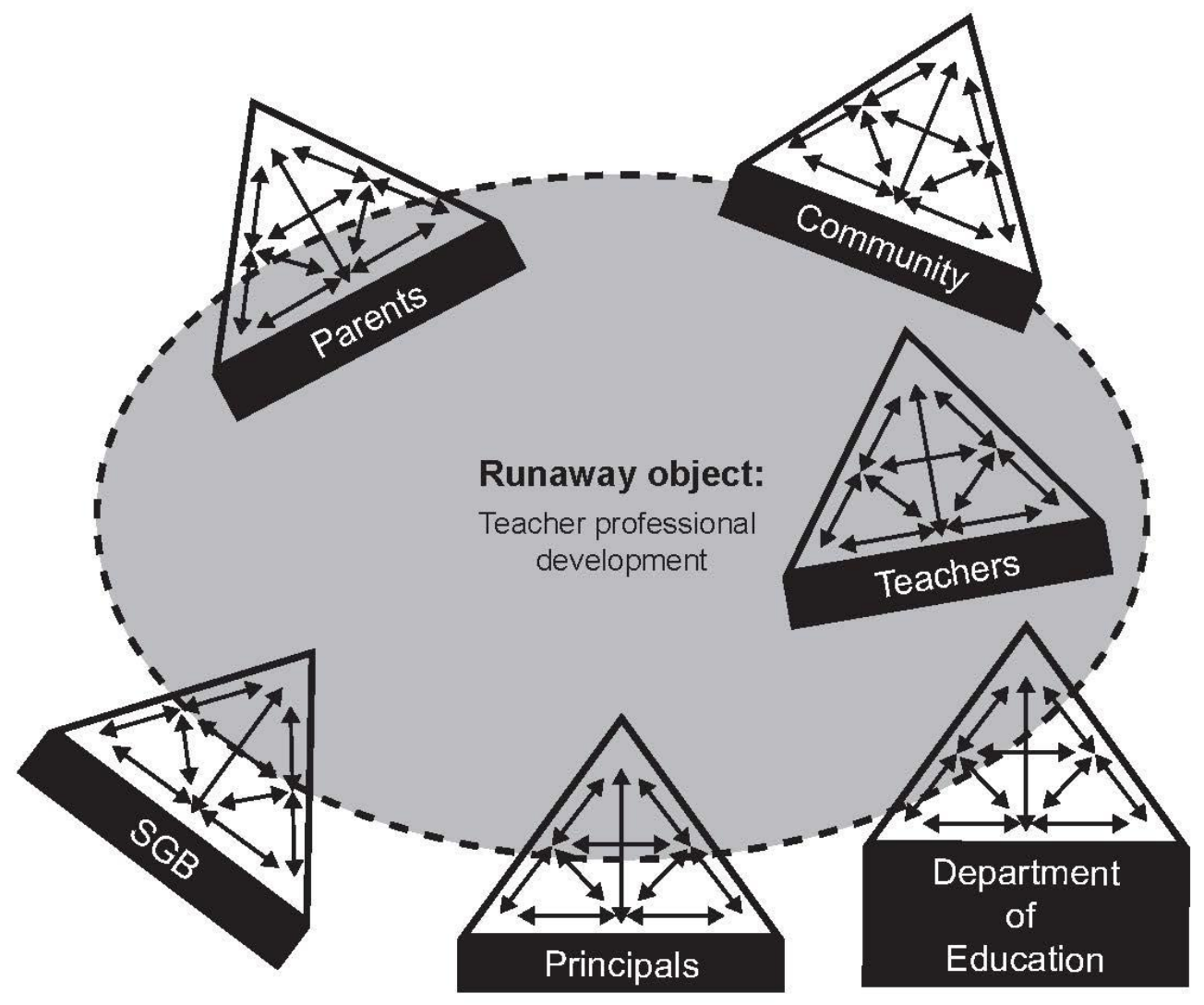

Fourth-generation CHAT, as conceptualized by Engeström (2008)

Figure 1. The authors' perspective on fourth generation CHAT, informed by the viewpoint of Engeström (2008:5)

\section{Design principles for the Change Laboratory}

In addition to the above Change Laboratory Process, we will also be mindful of three design principles. Engeström (1991:20) "acknowledges the risk of activity theory 
becoming an eclectic combination of ideas before it has a chance to redefine its own core". It is therefore essential that the Change Laboratory should be structured around well-considered design principles, in order to ensure that it provides the intended outcomes.

\section{(a) The expansive learning should be rooted in social constructivism}

The first such design principle, is that it should be rooted in social constructivism. We intend to structure the Change Laboratory around the four phases of Warford (2011) mentioned earlier, namely (a) all stakeholders to declare their viewpoints/ assumptions; [during phase (i) of the Change Laboratory Process above], (b) jointly redefine the "runaway object" [during phases (ii) and (iii) above]; (c) rethink own viewpoints, based on the newly constructed object [during phase (iv) above]; and (d) considering how to put the expansive learning into practice [phases $v$ and vi]. A sine quo non is that such a social learning space should be experienced as a "low-risk setting for learning" (Schön, 1987).

\section{(b) Elements of Cooperative Learning for effective cooperation}

Based on the Social Interdependence Theory as well as the Structure-Process Theory, Johnson and Johnson (2018) define five elements that should be intentionally structured and visible in every cooperative learning environment in order for it to be successful. The first element, positive interdependence, implies that there should be a feeling or perception among members of the group that they can achieve their goals only if the other members in the group also achieve their goals. The outcome of an individual's actions in the group should positively influence the outcomes of all the other members of the group (Teng \& Luo, 2015). Positive interdependence is essential for the productivity and effectiveness of a group and promotes promotive interaction among group members, which is the second essential element for structuring a cooperative learning activity (Johnson \& Johnson, 2018). Promotive interaction implies that group members interact in a way that are conducive to the success of all members (Cockerill, Craig and Thurston, 2018). It can be identified in the encouraging and supportive behavior towards each other to achieve the common goal by sharing resources, and showing a trust relationship (Johnson \& Johnson, 2007). This brings us to the third element, individual accountability which exists when all group members do their share of the work knowing that they will also be held accountable to achieve the goals set for the group. The fourth element and the glue holding the group together is social or interpersonal skills. Without good communication and listening skills, trust building and decision-making skills, a group will not be able to build good trust relationships and coherency. Lastly there should be group processing built into any cooperative environment where the effectiveness of the process can be assessed (Johnson \& Johnson, 2018). 
In the planning of the Change Laboratories we shall be guided by these elements, and positive interdependence will be structured by setting a clear goal to reach a common objective, provide the members of the different activity systems different roles and responsibilities and acknowledge the fact that they have different resources to bring to the discussion in order to reach the set objectives. It will be clearly stated that the different stakeholders from the different activity systems bring to the table different knowledge and insights and they therefore need to realise that each of them have a responsibility towards other stakeholders. They further need to realise that they all need each other's assistance, support, knowledge and insight in order to reach the common goal. Certain rules in terms of communication and listening skills will be set from the beginning in order to ensure that a promotive interaction will take place between all participants.

\section{(c) Eliminate or control power relations}

The expansive learning within the Change Laboratory should be inclusive, and every stakeholder should have a voice. It is therefore essential for the researchers and facilitators to be mindful of power relations that are present. French and Raven (1959) alerts to five bases of power. Kim, Pinkley and Fragale (2005:800) explain that person A's power over person B is determined by factors indicated in Table 1.

Table 1: The authors' take on French and Raven's typology of power bases (based on Kim, Pinkley and Fragale, 2005:800)

\begin{tabular}{|l|l|l|}
\hline Power base & Description & $\begin{array}{l}\text { How it could play out in } \\
\text { the Change Laboratory }\end{array}$ \\
\hline Reward power & $\begin{array}{l}\text { The extent to how much A } \\
\text { can reward B (or } \\
\text { perceptions of such } \\
\text { rewards) }\end{array}$ & $\begin{array}{l}\text { Parents could perceive } \\
\text { the teacher as having } \\
\text { reward power (unduly } \\
\text { influencing his/her child) } \\
\text { or a teacher identifying } \\
\text { reward power of the } \\
\text { principal (e.g. promotion if } \\
\text { he/she complies to } \\
\text { wishes). }\end{array}$ \\
\hline Coercive power & $\begin{array}{l}\text { A's ability to punish B, if B } \\
\text { does not comply with A's } \\
\text { wishes }\end{array}$ & $\begin{array}{l}\text { Teachers, or even } \\
\text { principals, might be } \\
\text { cautious to criticize the } \\
\text { Department of Education. }\end{array}$ \\
\hline Expert power & $\begin{array}{l}\text { A's power over B, due to } \\
\text { A's special knowledge or }\end{array}$ & $\begin{array}{l}\text { Members of the } \\
\text { community, and parents, }\end{array}$ \\
\hline
\end{tabular}




\begin{tabular}{|l|l|l|}
\hline & expertise & $\begin{array}{l}\text { might be intimidated by } \\
\text { the specialized } \\
\text { knowledge of teachers, } \\
\text { principals and officials } \\
\text { from the Department of } \\
\text { Education. }\end{array}$ \\
\hline Legitimate power & $\begin{array}{l}\text { A has lawful authority } \\
\text { over B }\end{array}$ & $\begin{array}{l}\text { Principals, school } \\
\text { governing bodies, and } \\
\text { officials from the } \\
\text { Department of Education, } \\
\text { has legitimate power over } \\
\text { teachers, and stand in } \\
\text { positions of authority, that } \\
\text { might intimidate other } \\
\text { stakeholders. }\end{array}$ \\
\hline Referent power & $\begin{array}{l}\text { The extent to which B } \\
\text { identifies with A }\end{array}$ & $\begin{array}{l}\text { A young teacher, fond of } \\
\text { his/her school principal, } \\
\text { might not be objective } \\
\text { due to referent power. }\end{array}$ \\
\hline
\end{tabular}

\section{Conclusion}

This paper set out to answer the research question, 'how can the impact and sustainability of well-designed SLP's be ensured?' Like in other countries, notably Finland and Brazil, third-generation CHAT has also provided nuanced insight into our teacher professional development intervention data in South Africa. Foot (2014:17) states that "contradictions can be understood as illuminative hinges that can open new vistas of understanding". The contradictions (tensions) identified by third-generation CHAT provided insight into factors that negatively impact on the transfer of newly acquired knowledge and skills in the post-intervention classroom. A major finding was that pressure from stakeholders such as parents and principals to 'teach to the test', and performance indicators from the department of education, negatively impact on the fostering of self-directed learning and $21^{\text {st }}$ century skills. It became clear that all stakeholders should be involved when planning and presenting professional development opportunities, in order to ensure that transfer take place in the classroom. This realization has led to a rhizomic development towards fourthgeneration CHAT, and the envisaged implementation of Change Laboratories. The Change Laboratories provide the opportunity to all stakeholders to engage in expansive learning, in order to come to a shared understanding of the object of the activity system. These Change Laboratories, we claim, hold affordances to enhance the impact and sustainability of short learning programs for teacher professional 
development, as stakeholders collectively engage in expansive learning for collective transformation.

The recommendation emerging from this research, is that Change Laboratories should precede professional development interventions. This could enhance the impact of costly educational programmes.

\section{REFERENCES}

Barber, M. and Mourshed, M., 2007. How the world's best-performing school systems come out on top. McKinsey \& Company.

Bartel, C.A. and Saavedra, R., 2000. The collective construction of work group moods. Administrative Science Quarterly, 45(2), pp.197-231.

Bronfenbrenner, U., 1977. Toward an experimental ecology of human development. American Psychologist, 37(7), pp.513 - 531.

Bernstein, A., 2011. Value in the classroom: The quantity and quality of South Africa's teachers.

Chen, C.T., Chen, C.F., Hu, J.L. and Wang, C.C., 2015. A study on the influence of self-concept, social support and academic achievement on occupational choice intention. The Asia-Pacific Education Researcher, 24(1), pp.1-11. doi: 10.1007/s40299-0130153-2.

Cockerill, M., Craig, N. and Thurston, A., 2018. Teacher Perceptions of the Impact of Peer Learning in Their Classrooms: Using Social Interdependence Theory as a Model for Data Analysis and Presentation. International Journal of Education and Practice, 6(1), pp.14-27.

Cole, M., 1988. Cross-cultural research in the sociohistorical tradition. Human development, 31(3), pp.137-157.

Cronje, A., De Beer, J. and Ankiewicz, P., 2015. The development and use of an instrument to investigate science teachers' views on indigenous knowledge. African Journal of Research in Mathematics, Science and Technology Education, 19(3), pp.319-332.

De Beer, J. and Mentz, E., 2016. Self-directed learning: Lessons from indigenous knowledge holders for school science education. Proceedings of the ISTE Conference on Mathematics, Science and Technology Education, 24 - 28 October 2016 (pp.543 - 553).

De Beer, J. and Ramnarain, U., 2012. The implementation of the FET Physical-and Life Sciences curricula: Opportunities and challenges. unpublished report prepared for the Gauteng Department of Education, UJ Library, University of Johannesburg. 
Deutsch, M., 1949. A theory of co-operation and competition. Human relations, 2(2), pp.129-152.

Deutsch, M., 1994. Constructive conflict resolution: Principles, training, and research. Journal of social issues, 50(1), pp.13-32.

Engeström, Y., 1987. Learning by expanding: An activity-theoretical approach to developmental research. Helsinki: Orienta-Konsultitl.

Engeström, Y., 1991. Developmental work research: Reconstructing expertise through expansive learning. In M.I. Nurminen \& G.R.S. Weir (Eds.), Human jobs and computer interfaces: Proceedings of the Ifip Wg 9.1 Working Conference on Human Jobs and Computer Interfaces.

Engeström, Y., 2001. Expansive learning at work: Toward an activity theoretical reconceptualization. Journal of education and work, 14(1), pp.133-156.

Engestrom, Y., 2008. The future of activity theory: A rough draft. University of Helsinki. In Keynote Lecture Provided at the ISCAR Conference (pp. 8-13).

Engeström, Y., 2011. 'From design experiments to formative interventions', Theory and Psychology, 21(5), pp. $598-628$.

Engeström, Y., Rantavuori, J. and Kerosuo, H., 2013. Expansive learning in a library: Actions, cycles and deviations from instructional intentions. Vocations and Learning, 6(1), pp. 81-106.

Englund, C. and Price, L., 2018. Facilitating agency: the change laboratory as an intervention for collaborative sustainable development in higher education. International journal for academic development, 23(3), pp. 192-205.

Foot, K.A., 2014. Cultural-historical activity theory: Exploring a theory to inform practice and research. Journal of Human Behavior in the Social Environment, 24(3), pp.329-

347.Accessed online: http://faculty.washington.edu/kfoot/Publications/Foot-CHAT-exploreddist-tf.pdf.

French, J.R., and Raven, B., 1959. The bases of social power. In: D. Cartwright (Ed), Studies in social power, pp.150 - 167. Ann Arbor: University of Michigan Press.

Gretschel, P., Ramugondo, E.L. and Galvaan, R., 2015. An introduction to Cultural Historical Activity Theory as a theoretical lens for understanding how occupational therapists design interventions for persons living in low-income conditions in South Africa. South African Journal of Occupational Therapy, 45(1), pp.51-55. http://dx.doi.org/10.17159/23103833/2015/v45no1a9.

Igira, F.T.,and Gregory, J., 2009. Cultural-Historical Activity Theory. In: Y.K. Dwivedi, B. Lal, M. Williams, S. Schneberger \& M.R. Wade (Eds), Handbook of Research on Contemporary Theoretical Models in Information Systems. IGI Global. 
Johnson, D.W. and Johnson, R.T., 2009. An educational psychology success story: Social interdependence theory and cooperative learning. Educational researcher, 38(5), pp. 365-379.

Johnson, D. and Johnson, R., 2018. Cooperative Learning as the foundation for active learning. In Active Learning. IntechOpen.DOI:10.5772/intechopen.81086

Johnson, D. W., Johnson, R., and Smith, K. 1998. Active learning: Cooperation in the college classroom (2nd ed.). Edina, MN: Interaction Book Company.

Johnson, D.W., Johnson, R.T. and Stanne, M.B., 1989. Impact of goal and resource interdependence on problem-solving success. The Journal of Social Psychology, 129(5), pp. 621-629.

Kim, P.H., Pinkley, R.L. and Fragale, A.R., 2005. Power dynamics in negotiation. Academy of Management Review, 30(4), pp. 799-822.

Knowles, M., 1975. Self-directed learning: A guide for teachers and learners. Chicago, IL: Follett.

Koffka, K., 1935. Principles of gestalt psychology. New York: Harcourt, Brace.

Kozulin, A., 2002. Sociocultural theory and the mediated learning experience. School psychology international, 23(1), pp. 7-35.

Kozulin, A., 2004. Vygotsky's theory in the classroom: Introduction. European Journal of Psychology of Education, 19(1), pp. 3-7.

Kuutti, K., 1996. Activity theory as a potential framework for human-computer interaction research. Context and consciousness: Activity theory and human-computer interaction, 17 44.

Leont'ev, A.N., 1978. Activity, consciousness, and personality. Prentice Hall.Lewin, K. 1935. A dynamic theory of personality. New York: McGraw-Hill.

Luriia, A.R., 1976. Cognitive development: Its cultural and social foundations. Harvard university press.

McNeil, L.M., 2013. Contradictions of control: School structure and school knowledge. Routledge.

Mentz, E., \& De Beer, J., 2017. The affordances of Cultural-Historical Activity Theory as a research lens in studying education from a socio-economic perspective. IISES Proceedings of the Fourth Teaching and Education Conference, Venice, April 2017, 88 - 103. 
Mentz, E., and De Beer, J., 2019. The use of Cultural-Historical Activity Theory in researching the affordances of indigenous knowledge for self-directed learning. In: J. de Beer (Ed), The decolonization of the curriculum project: The affordances of indigenous knowledge for self-directed learning. Stellenbosch: AOSIS.

Nussbaumer, D., 2011. An overview of cultural historical activity theory use in classroom research 2000 to 2009. Educational Review 64(1), pp. 37 - 55.

Onwuegbuzie, A.J., Collins, K.M. and Jiao, Q.G., 2009. Performance of cooperative learning groups in a postgraduate education research methodology course: The role of social interdependence. Active Learning in Higher Education, 10(3), pp. 265-277.

Piaget, J., 1970. Piaget's theory, Carmichael's manual of child psychology.

Pretorius, E.D., 2015, Learning communities for the professional development of science teachers, University of Johannesburg, unpublished PhD thesis.

Ramnarain, U. and Schuster, D., 2014. The pedagogical orientations of South African physical sciences teachers towards inquiry or direct instructional approaches. Research in Science Education, 44(4), pp. 627-650.

Roseth, C.J., Lee, Y.K. and Saltarelli, W.A., 2019. Reconsidering jigsaw social psychology: Longitudinal effects on social interdependence, sociocognitive conflict regulation, motivation, and achievement. Journal of Educational Psychology, 111(1), pp. 149 - 169.

Sawada, D., Piburn, M.D., \& Judson, E., 2002, Measuring reform practices in science and mathematics classrooms: The reformed teaching observation protocol. School Science and Mathematics 102(3), pp. $245-253$.

Schein, E.H. 1996. Kurt Lewin's Change Theory in the field and in the classroom: Notes toward a model of managed learning. Reflections, 1(1): pp. 59-74.

Schön, D.A., 1987. Educating the reflective practitioner. San Francisco, Jossey Bass.

Slavin, R.E., Hurley, E.A. and Chamberlain, A., 2003. Cooperative learning and achievement: Theory and research. Handbook of psychology, pp. 177-198. https://doi.org/10.1002/0471264385.wei0709.

Teng, C.C. and Luo, Y.P., 2015. Effects of perceived social loafing, social interdependence, and group affective tone on students' group learning performance. The Asia-pacific education researcher, 24(1), pp. 259-269.

Veresov, N., 2010. Introducing cultural historical theory: main concepts and principals of genetic research methodology. Cultural Historical Psychology (Translated from Russian). pp. $83-90$. 
Virkkunen, J., \& Newnham, D.S., 2013, The Change Laboratory: A tool for collaborative development of work and education, Rotterdam, Sense Publishers.

Vygotsky, L.S., 1978. Mind in society. London: Harvard University Press.

Vygotsky, L.S. 1981. The genesis of higher mental functions. IN: J.V. Wertsch (ed), The concept of activity in Soviet psychology, $144-188$.

Warford, M.K., 2011. The zone of proximal teacher development. Teaching and Teacher Education 27(1), pp. $252-258$.

Zeichner, K.M. and Tabachnick, B.R., 1981. Are the effects of university teacher education 'washed out' by school experience? Journal of teacher education, 32(3), pp. 7-11. 